\title{
The Role of EFL Teachers in the ESL Setting ${ }^{1}$
}

\author{
Ana Tristana Solano Campos ${ }^{2}$ \\ Universidad Nacional, Costa Rica
}

\section{RESUMEN}

Se describen las acciones que los profesionales de la enseñanza del ingles como lengua extranjera deben llevar a cabo al trasladarse a un contexto en el que se aprende el idioma como segunda lengua. Se subraya la función de esos profesionales como defensores y tutores de estudiantes con diversidad cultural y lingüística. Asimismo, se señalan los importantes aspectos por tener en cuenta para cumplir con esa función.

\section{Abstract}

A description is provided of the challenges that English as a Foreign Language teaching professionals face when being relocated to an English as a Second Language setting. Language teaching professionals' role as advocates and educational parents to Culturally and Linguistically Diverse (CLD) students is highlighted. The most important aspects to take into account to fulfill such a role are also presented.

Palabras clave: Enseñanza del Ingles como segunda lengua. diversidad cultural y' linguiística. función del educador.

Keywords: English as a second language, cultural and linguistic diversity, language teaching professional's role.

Paper presented in the I Congreso Internacional de Lingïistic a Aplicada. CILAP). held in October 2007 (Campus Omar Dengo. Universidad Nacional. Costa Rica).

: Correo electrónico: anatris@yahoo.com 
One looks back with appreciation to the brilliant teachers, but with gratitude to those who touched our human feelings. The curriculum is so much necessary raw material, but warmth is the vital element for the growing plant and for the soul of the child.

$\sim$ Carl Jung

What can teachers do when 19 of 25 students in their class do not speak the teachers' language? How can they teach the students mathematics, social studies, or science? Worse yet, what can teachers do if all nineteen students speak nineteen different native languages? This complex situation is unknown for many English as a Foreign Language teaching professionals, especially those who work in countries with a relatively homogenous cultural and linguistic population. However, in countries like the United States, where immigration patterns have changed drastically, it is not hypothetical; it is a reality. In fact, in recent years, the number of "non-English speaking" students in the U.S. has increased in some states by 200 percent. Lilburn Elementary School (LES), in Georgia, is an example of such change. Seventy-seven percent of the 1,393 students at LES speak one of 34 different languages. Spanish, Vietnamese and Arabic are among the most common languages spoken in this school. ${ }^{3}$ In fact, the United States Census Bureau projects that by the year 2030, 40\% of the children enrolled in kindergarten, elementary, and middle school in the U.S. will not speak English as their native language. ${ }^{4}$ In other words, around 120 million people, almost half of the U.S. population will speak a language other than English as their native language.

Educating such a large number of children when they do not

Gwinnett County Public Schools, History of Lilburn Elementary School, <http:// w'ww:gwinnett.k 12.ga.us/gcps-mainweb01.nsf/4519F73A7CFC 1936852572ED004B60AC/ \$file/ LilburnES.pdf> (accessed September 26. 2007).

4 Socorro G. Herrera and Kevin G. Murry, Mastering ESL and Bilingual Methods: Differentiated Instruction for Culturally and Linguistically Diverse (CLD) Students (Boston. MA: Pearson Education, 2005) 5 . 
speak the language of the majority is a significant challenge for educational authorities in the U.S. as well as for the children themselves. However, the difficulties that students with a first language other than English face cannot be narrowed to language alone. Many of those children arrive to the United States from war-torn countries; others reside in the U.S. under dubious immigration status. In either case, students have usually missed months or even years of schooling. Having left all they owned back in their home country, they are raised in poverty with little or no access to books, computers, or tutors. Not only that, they also carry with them a big load of emotional baggage. Sadly, students of English as a second, third, or fourth language or Culturally and Linguistically Diverse (CLD) students, ${ }^{5}$ often have many challenges to overcome and very little linguistic, academic, and cultural support when they first arrive in American schools. Their unique circumstances require unique teaching methods to address their individual affective needs.

Teachers in American schools work hard to provide CLD students with the tools to improve their Basic Interpersonal Communication Skills (BICS) and their Cognitive Academic Language Proficiency (CALP). Unfortunately, some teachers frequently overlook creating a nurturing and culturally safe environment that ensures students' success. Because of this, English as a Foreign Language (EFL) teaching professionals that relocate to teach in an English as a Second Language (ESL) setting, such as the United States, must be aware of the current educational issues taking place in that setting. Not only that, they must be aware of their role as cultural ambassadors, students' advocates, and staff development speakers. It is their responsibility to motivate other teachers with little knowledge of students' language, cultural differences and life circumstances to understand the implications of going to school under such strenuous circumstances. Understanding their own attitude towards different

\footnotetext{
Herrera and Murry. 8.
} 
cultures and languages, exercising empathy, exploring the stages of culture shock, and having high expectations of the CLD students are key elements EFL teachers must develop in order to fulfill students cultural and affective needs.

\section{Educational Background}

To better understand the extent of EFL teaching professionals' role in an ESL context, it is imperative to provide a brief review of the history and current situation of significant teaching practices and testing policies in the U.S. and all over the world.

\section{Humanism and Constructivism}

In the 1950's, psychologists such as Erikson, Maslow, and Rogers gave birth to Humanism. This school of psychology "emphasized the importance of the inner world of the human being and places the individual's thoughts, feelings and emotions at the forefront of all human developments." "Humanists highlighted the importance of social interaction, human needs, and meaningful learning. Before that time, students' feelings were rarely taken into account in language teaching because the emphasis had been placed mostly on the subject matter.

In the 1970's, the influence of Humanism on language teaching gave its first fruits: the Humanistic Approach. This approach focused "less on materials, techniques and linguistic analyses, and more on what goes on inside and between the people in the classroom."7 Three main methods, the Silent Way, Suggestopedia, and Community Language Learning arouse from it. These methods placed emphasis on increasing student involvement, creating an anxiety-free teaching environment, and carrying out collaborative learning-teaching

\footnotetext{
( Guilian Wang, "Humanistic Approach and Affective Factors in Foreign Language Teaching.," SinoUS English Teaching, 5 (2005): 1.

7 E. Stevick. Teaching Language: A Way and Way's (Rowley. MA: Newbury House. 1980), quoted in Wang. Humanistic, 2.
} 
activities. ${ }^{8}$ By that time, Constructivists such as Dewey, Ausubel, Vygotsky and Piaget had also highlighted the importance of the social and cognitive contexts in the teaching-learning process. They perceived learning as the active construction of knowledge by the learner, who incorporates new information to previous knowledge. ${ }^{9}$

Both, Humanism and Constructivism prompted a change in the way language teaching was delivered. The language classroom experienced a shift in power. The teacher's role had become that of a counselor, guide or facilitator, letting students take center stage.

\section{Teaching and Testing Policies Overview}

While most scholars, educational authorities, and teachers in the U.S. agree that educators should tailor instructional methods and techniques to fulfill students' needs, reality does not always portray this. Contradictory as it seems, current teaching and testing policies make it very difficult for educators to spend time providing students with cultural and individualized support. The No Child Left Behind (NCLB) education act, passed in 2001, demands accountability for all students' scores on standardized tests. The NCLB act also outlines drastic consequences for the schools that fail to comply with the Adequate Yearly Progress (AYP) mark it specifies. CLD students whose English and academic language skills are low and who are also facing culture shock, are expected to achieve the same standards as native speakers of the language. As a result, school systems have rearranged their priorities and stopped focusing on the student in order to focus on the subject matter.

Traditionally, CLD students had been denied access to the content area curriculum because of their limited English proficiency. They were usually pulled out of their classroom to an ESL class in which the learning of the English language was the main objective,

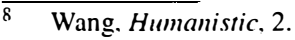

$9 \quad$ William G. B. Huitt. "Constructivism." Educational Psycholog.' Interactive. <http://chiron.valdosta.edu/whuit//col/cogsys/construct.html> (accessed September 26. 2007).
} 
thus missing mathematics, science and social studies instruction. The NCLB act provided an opportunity for CLD students to finally be considered as active participants in their classrooms. Nevertheless, it also created "a predictable tendency among educational practitioners, whose performance evaluations and employment may depend on student standardized test scores, to "teach to the test." 10

Moreover, standardized tests in English are administered to CLD students to measure AYP. In addition to the anxiety and stress this causes to students, high stakes decisions based on students' test results are made in regards to their education. These decisions do not only affect students' high school graduation but also influence their highereducation and job opportunities in the future. Although Humanist and Constructivist principles are widely accepted and supported by the educational community in the United States and all over the world, the educational system in the U.S., as in many other countries, favors such principles in theory but discourages a humanist and constructivist view of teaching and learning in the practice.

\section{Current Teaching Methods}

Because of the requirement imposed on CLD students by the NCLB act. the educational emphasis has switched from communicative English to Content-Based Instruction. Current research and teaching methodologies have demonstrated that CLD students can and should develop both, the oral skills that will lead to survival in social contexts and the content-area skills that will help them in the academic context. Cummins calls those survival skills Basic Interpersonal Communication Skills (BICS), and refers to the academic skills as Cognitive Academic Language Proficiency (CALP). ${ }^{11}$ As a result, many methods have emerged in the Teaching of English to Speakers of Other Languages

\footnotetext{
10 H. Berlak. "Standards and the Control of Know'ledge." Rethinking Schools 13. 3 (1999). quoted in Herrera and Murry, Mastering. 47.

1" Jim Cummins. "BICS and CALP: Clarifying the Distinction." Dr: Cummins' ESL and Second Language Learning Web, <http://www.iteachileam.com/cummins/bicscalp.html> (accessed June 14. 2007).
} 
(TESOL). The Sheltered Instruction Observation Protocol (SIOP), the Cognitive Academic Language Learning Approach (CALLA), and the Integrated Content Based Approach (ICB) areamong the approaches that look to develop content area specific vocabulary and skills while teaching English to CLD students. These approaches stress the use of language learning strategies, cognitive principles, and content-area grade level materials.

Once again, affective needs remain in the margin. Current teaching and testing policies leave very little time for teachers to get to know their CLD students better. Still, teachers stay vigilant in the hope that this wave of contemporary language teaching methods can fulfill CLD students' needs and federal and state testing expectations as well. Far from that, CLD students struggle to overcome the pressure imposed on them by the school system.

\section{EFL Teachers: Students' Advocates}

As seen above, being a CLD student in the United States is not an easy task. Academic and cognitive skills alone do not do much for students if they are afflicted, fearful, lonely or hungry. Still, many educators might not relate to the students' experiences and difficulty to adapt to the new country. Luckily, EFL teaching professionals who have relocated to the United States or another ESL setting have also experienced the challenges of living and working in a new cultural and linguistic environment. They have the knowledge and power to make other educators aware of four important aspects to better understand and fulfill their CLD students' needs: cultural attitude, culture shock, empathy and educational expectations.

\section{Cultural Attitude}

Many assumptions about CLD students are based not on language alone but also on nationality, physical appearance, socio-economic status, and educational background. Underlying stereotypes of these 
traits might lead to prejudice and discrimination in the classroom, affecting the outcome of the teaching and learning process. As Ovando, Combs and Collier state, "the positive or negative perceptions of the mainstream population towards the minority population can affect the academic performance of language minority students as they internalize these perceptions."12

The terms used to refer to CLD students in school systems through out the country, such as Language Minority Students (LMS), English Language Learner (ELL), and Non-English Proficient (NEP), exemplify the way assumptions about CLD students are created and spread unconsciously. These acronyms focus on students' "lack" of something and imply that students are seen as a burden on the educational system instead of focusing on their cultural assets. This perspective holds that CLD students are language (presumably English) deficient and culture and home deficient and, as a result, at risk of academic failure. In one sense, the prevalence of this liability or deficit perspective is not surprising given the fact that the United States is one of the few countries in the world that does not value either bilingualism or multilingualism.

CLD students do have culture, home, and valuable life experiences; they just cannot always communicate them effectively. Teachers who unknowingly expose their students to biased information, activities, or behaviors, may be damaging the perspective that students have of themselves and of others permanently. To avoid doing that, all teachers of CLD students should take the time to research students' countries and their history a well as the language they speak and how different it is from English. The old proverb, "ignorance is the mother of all evil," highlights the importance of knowing about the culture and language of CLD students. Making inaccurate judgments about CLD students' linguistic, social and academic skills is less likely to occur if teachers have background information about the students' country and

\footnotetext{
12 Carlos J. Ovando. Mary Carol Combs and Virginia P. Collier, Bilingual \& ESL Classrooms: Teaching in Multicultural Contexts, 4th ed. (New York: McGraw Hill. 2006) 18.
} 
language. Because a person's culture usually influences the way they perceive others' actions, inviting teachers to reflect first on their own beliefs and attitudes towards their culture and towards their students' cultures is a relevant step in promoting tolerance in the classroom.

\section{Culture Shock}

Another element teachers should take into account when working with CLD students is culture shock. Anthropologist Kalervo Oberg first coined this term in the 1960's. ${ }^{13}$ Oberg, described culture shock as a "malady...precipitated by the anxiety that results from losing all our familiar signs and symbols of social intercourse." ${ }^{14}$ When students move to the United States, not only do they have to learn a new language, they also have to deal with strong emotions of grief: they have left relatives, friends, and places that embedded their cultural identity, the core of who they are.

Idealized, the United States usually represents a safe heaven for many CLD students. Hence, the first stage is characterized by excitement and curiosity. In the second stage. however, reality strikes. In the new culture, everything looks different. Extensive amounts of energy are used to do tasks that back in their native country required little or no effort. The sole act of navigating through the school halls without getting lost generates a great deal of anxiety for CLD students. People in the new environment also act differently. New sets of procedures, rules and social codes must be learned in order to succeed. What students knew back home might or might not be useful in the new context. During the third stage, children start to feel comfortable in the new environment and start to develop a new cultural identity. It is in this stage that the children assimilate, replacing their native culture with that of the United States, or acculturate, integrating cultural

1.3 Rachel Irwing. "Culture Shock: Negotiating Feelings in the Field," Anthropology. Matters Joumnal 9. 1 (2007). http://w'w'w.anthropology'matters.con/_journal/2007-1/irwin_2007_culture.htm\#author (accessed Sept. 26, 2007).

It Kalervo Oberg. Culture Shock. http://ww'w. lib.calpoly.edu/staff/fvuotto/research_comer/research_ guides/cultural/cultureshockarticle.pdf (accessed September 26. 2007). 
patterns of both cultures. ${ }^{15}$ In the fourth stage, students would have overcome the initial uneasiness, isolation, and confusion. Instead, they would have developed the necessary skills to not only survive but also enjoy living in the United States. ${ }^{16}$ Finally, if students go back to their home country, the experience of culture shock will possibly repeat itself. ${ }^{17}$

Not all cultural transitions are as successful or as smooth as that described above. After living in the United States for a long period of time, CLD students might still be struggling with mixed feelings about their origins and their place in their new home, even if they do not show it. Culture shock is especially problematic for CLD students because of the social and economic hardships they go through; however, its impact on students remains foreign to many teachers, especially those who have never lived abroad. Therefore, when CLD students show poor academic performance, tiredness, behavior problems, adaptation issues and mood changes, educators blame the children's cultural background. Unaware of the process students are going through, teachers sometimes will repeat stereotypes and make remarks such as "No wonder he is so lazy, he is Hispanic." Because of this, teachers should be made aware of the effects that moving to another country can have on a person's physical, emotional, and intellectual abilities.

Likewise, teachers and students have to realize that the process of acculturation takes time and affects the students' performance in the classroom in unpredicted ways. There is not an "easy fix" for the emotions and behaviors that arise during culture shock. However, Igoa believes that "[i]n the transplant, it is customary for the gardener to take as many of the plants roots as possible to the new ground. In the uprooting experience, the child's family must do the same. Teachers

\footnotetext{
15 Cristina Igoa. The Inner World of the Immigrant Child (New Jersey: Lawrence Erlbaum Associates. 1995).

16. Irwin. "Culture Shock."

1) Geneva College. Cultural Transitions Re-entr. Shock, http://www.geneva.edu/objecucrossroads_ct_ reentryshock_page (accessed September 26. 2007).
} 
as 'gardeners' of these seedlings need to understand the importance of cultural roots." 18

Validating students' culture while introducing the new culture will help them develop a sense of worth of who they are while they explore who they can be. Knowing what culture shock is and the different stages it encompasses helps teachers guide students in adapting to their new surroundings. CLD students find comfort in the knowledge that they are going through stages which will eventually lead to wonderful transformations. Like the caterpillar that turns into a butterfly, with support from the teacher, CLD students will come out of their chrysalis when they are ready.

\section{Empathy}

There is no better way to understand what CLD students go through than by actually going through the same experiences: immigration, war, extenuating economic hardships, interrupted schooling and second language acquisition. Since that is not likely to happen, empathy plays a crucial role in educating CLD students. Understanding where students come from and how their life experiences have shaped their rate of learning provides a better view of what students need.

Learning a language and migrating to another country are unique experiences that not many people can relate to unless they have gone through those experiences themselves. Teachers who work with CLDs are more likely to care genuinely for a student if they are familiar with those experiences. Teachers who know another language or have lived in another country are better equipped to help CLD students. They can draw from their own experience to support students emotionally and identify with them. By doing this, they enhance the teacher-student bond.

18 Igoa. 40. 


\section{High Expectations}

Finally, a "nurturing approach" does not imply a reductionist approach. Although "often educators associate a limited ability to speak the language with an ability to perform academic tasks at grade level, ${ }^{19}$ CLD students must be challenged. They need level appropriate highly demanding tasks; tasks that motivate them to use their prior knowledge. Feelings of success help shape their self-image in a positive way and allow for confidence in their abilities to develop.

As Igor states, "nurturance is what they need, but not the kind of nurturance that weakens them or fosters dependence on the teacher." 20 Teachers should have high, realistic expectations of CLD newcomers. It is in these stages that students learn habits and routines that can help them cope with the academic load and social demands they will encounter. A meaningful, caring relationship with each student will provide the tools to decide how hard to push a student and avoid frustration in the classroom. CLD students' self concept needs to be reinforced.

\section{Concluding Remarks}

Carl Jung's quote at the beginning of this paper reveals that teaching content and academic skills is important, but that there is much more to the teaching of CLD students. Such an endeavor requires deep awareness of one's attitude towards different cultures, profound knowledge of the process of acculturation, insightful understanding of students' life experiences and feelings and true, high expectations of the students. All of these together, create a strong bond between teacher and student. Such a bond lowers students' affective filter and provides the conditions for meaningful and long-lasting learning. Igoa points out that teachers need to be "educational parents." 21

\footnotetext{
19) Herrera and Murry. 53

21) Igoa. 5.

21 Igoa, 103.
}

190 
Being an educational parent becomes more difficult when there are cultural and linguistic barriers in the classroom. Therefore, it is the EFL teacher's job to encourage other educators to debunk stereotypes, open their minds, and experience culture in a way that helps develop nurturing relationships with their students: the kind of relationships in which "the teacher [is the] person whom the student admires and emulates and with whom he or she can share deep feelings—a trusted adult.",22 